Etnografia. Praktyki, Teorie, Doświadczenia 2015, 1: 108-132

FILIP WRÓBLEWSKI

Uniwerstytet Jagielloński

\title{
Indeksy etnograficzne w polskiej praktyce badawczej XX w. ${ }^{1}$
}

W ertując archiwalne materiały etnograficzne, można niekiedy, całkiem przypadkowo, natknąć się na interesujące opisy i wyimki odnoszące się do trudów i radości pracy terenowej, oddanych wprost lub stopniowo ujawniających się podczas lektury. W listopadzie 1966 r. Barbara Michniowska zapisała zwięźle: „wywiad niedokończony z powodu złego stanu zdrowia informatorki. Po raz drugi podjęta próba wywiadu nie dała rezultatu" (MEK 72073, t. 222/776)². Stając wobec sprawozdawczej lakoniczności mającej świadczyć

${ }^{1}$ Zasadniczy zrąb niniejszego artykułu powstał w 2010 r. jako referat przygotowany na IV Międzyuczelnianą Konferencję Antropologiczną „Teren w ścisłym tego słowa znaczeniu. Problemy etyczne". Na potrzeby publikacji zmieniono oraz uzupełniono tekst o materiały i wiedzę będące wynikiem projektów badawczych: „Etnografia jako doświadczenie osobiste. Generacyjne uwarunkowania przemian metodologii i praktyk badawczych" finansowanego przez Narodowe Centrum Nauki (2011-2013, nr 2011/01/N/HS3/03273), „Wyznaczniki dyskursu scjentystycznego w etnologii na przykładzie materiałów Polskiego Atlasu Etnograficznego" (2012-2013), „Znaczenie Międzyuczelnianych Obozów Etnograficznych dla rozwoju metodologii badań etnograficznych" (2013-2014) oraz „Maria Znamierowska-Prüfferowa wobec dyskusji o programie nauczania etnografii" (2014-2015) finansowanych przez Wydział Historyczny Uniwersytetu Jagiellońskiego. Na ręce Magdaleny Dolińskiej, Zdzisława Nowaka oraz Łukasza Sochackiego składam podziękowania za lekturę pierwszej wersji tekstu.

${ }^{2}$ Skróty podane w przywołaniach materiałów archiwalnych oznaczają kolejno: MAE - spuścizna Kazimiery Zawistowicz-Adamskiej w zasobie Archiwum Etnograficznego Muzeum Archeologicznego i Etnograficznego w Łodzi; MEK - zasób archiwalny Pracowni Dokumentacji Polskiej Sztuki Ludowej Instytutu Sztuki PAN w Krakowie przechowywany w archiwum Muzeum Etnograficznego im. Seweryna Udzieli w Krakowie; MET - spuścizna Marii Znamierowskiej-Prüfferowej $\mathrm{w}$ zasobie archiwum Muzeum Etnograficznego $\mathrm{w}$ Toruniu; PAE - kartoteka informatorów terenowych w archiwum Instytutu Etnologii i Antropologii Kulturowej Uniwersytetu Śląskiego w Cieszynie; PAN - archiwum krakowskiego oddziału Ośrodka Etnologii i Antropologii Współczesności PAN; UJ - materiały terenowe z archiwum Instytutu Etnologii i Antropologii Kulturowej Uniwersytetu Jagiellońskiego. Cyfry umieszczone po skrócie oznaczają kolejno numer inwentarzowy, a następnie strony lub lokalizację dokumentu, w zależności od przyjętego w danej jednostce sposobu oznaczania materiałów. We wszystkich cytatach pochodzących ze źródeł archiwalnych zachowano oryginalną pisownię oraz podkreślenia. 
o „naukowym” realizmie dokumentu, zaintrygowany czytelnik może zadawać sobie pytania: na co cierpiała rozmówczyni badacza? Dlaczego etnograf o tym milczy? Czy Michniowska była skłonna pomóc kobiecie i czy rzeczywiście coś $\mathrm{w}$ tym względzie uczyniła?

Zanim przyjdzie odpowiedzieć na te i inne pytania, warto określić przedmiot oraz cel niniejszej analizy. Artykuł ten ma charakter wstępnej, wycinkowej prezentacji problematyki z zakresu archiwistyki etnograficznej nakierowanej na "archeologię" procesu kształtowania metodologii prowadzenia badań terenowych w Polsce. Jest zatem pierwszą z kilku zaplanowanych publikacji. Kolejne będą systematycznie rozwijać wątki tutaj ledwie sygnalizowane, takie jak: sprawczość badanych, status ontologiczny danych, procedury i systemy archiwizacyjne, polityczny i ideologiczny wymiar badań, media i techniki terenowe czy wreszcie samo „wynalezienie” metodologii.

W niniejszym tekście uwaga będzie poświęcona indeksom etnograficznym, czyli inskrypcjom, jakimi opatrywano materiały terenowe. Miały one za zadanie dostarczać badaczom szeregu sprofilowanych informacji na temat poszczególnych rozmówców lub całej badanej społeczności. W pierwszej kolejności zostanie omówione tło teoretyczne wywodu, następnie formowanie oraz przekształcanie paradygmatu praktykowania etnografii. Dalsza część artykułu będzie natomiast poświęcona wybranym instrukcjom i wytycznym, a wreszcie samym indeksom. Taki układ pozwoli na nakreślenie kontekstu historycznego i metodologicznego, który doprowadził do wyodrębnienia się rozpatrywanego typu adnotacji dotyczących osób badanych.

\section{Ramy teoretyczno-metodologiczne}

Podjęta problematyka sytuuje się na przecięciu trzech perspektyw teoretycznych. Będzie to kolejno postfoucaultowska krytyka relacji władzy i dominacji, ujęcie medioznawcze skupiające uwagę na mechanizmach i narzędziach administrowania oraz teoria piśmienności kładąca nacisk na zależność trybów komunikacyjnych względem stylów myślenia i organizacji społeczeństwa.

Antropologia obok innych nauk społecznych, poprzez walor informacyjny, od zawsze znajdowała się na przecięciu między polem nauki a płaszczyzną administracji i inżynierii społecznej. Jak pokazał Jack Goody (2006: 170), właściwa jej zdolność generowania olbrzymich zasobów danych w postaci systematycznej dokumentacji pełni funkcję procesów ładotwórczych. W systemie nauki przedmiotem zainteresowania etnografów stała się kultura z szeroką paletą rozmaitych sposobów życia. W systemie wiedzy każda z dyscyplin dostarcza konkretnych, wyspecjalizowanych wyjaśnień. Ich wspólną cechą jest postać tekstowa. Tak gromadzone informacje z powodzeniem mogą zostać wykorzystane w celu wzbogacenia wiedzy rządzących (Goody 2006: 172). Wzrostowi wiedzy, jak za Michelem Foucaultem przekonuje Goody (2006: 173), odpowiada wszak zwięk- 
szenie zdolności rządzenia. Nie inaczej jest $\mathrm{z}$ etnografią. Nie chodzi tu bynajmniej o bezpośrednie związki z aparatem państwowym, lecz o funkcjonowanie dyscypliny $\mathrm{w}$ swoistym dla danego społeczeństwa otoczeniu instytucjonalno-organizacyjnym. W tym sensie sama zależność będzie raczej polegała na uwikłaniu $\mathrm{w}$ rozproszoną sieć instytucjonalnych powiązań. Ponadto gromadzonej wiedzy nie sposób ukryć, co pośrednio warunkuje wewnętrzna logika środowiska naukowego nakierowana na upowszechnianie uzyskanych wyników. W warunkach PRL-u o informacje można było poprosić, nie istniały przeszkody, by je wykraść albo wymusić, wreszcie - dało się je także zamówić. Przykładem ostatniej ewentualności były, jedne $\mathrm{z}$ wielu podobnych, badania dotyczące przemysłu wiejskiego i małomiasteczkowego, prowadzone przez Polskie Towarzystwo Ludoznawcze w 1948 oraz 1949 r. na zlecenie najpierw Centralnego Urzędu Planowania, a następnie Państwowej Komisji Planowania Gospodarczego.

Etnografia poprzez samo generowanie informacji, gromadzenie ich oraz obrót nimi wpisuje się w typ instytucji powołanych do sprawowania kontroli nad populacją (Foucault 2010:355). Choć rzadko kiedy jej przedstawiciele aspirowali do takiej pozycji, z powodzeniem pełnili rolę pomocniczą. Wynika to z konstytutywnej podstawy etnografii, jaką jest drobiazgowa obserwacja szczegółu i ewidencjonowanie go, połączone z bezpośrednią bliskością z ludźmi. Skutkiem tego wytworzony zostaje "cały zespół technik, cały korpus metod i wiedzy, opisów, recept i danych" (Foucault 1998: 136) służących lepszemu opisowi, dokładniejszemu rozpoznaniu. Jej składowymi są nie tylko publikacje, raporty i sprawozdania, lecz również dokumenty przygotowywane na użytek wewnętrzny, mające pełnić rolę poświadczenia oraz źródła informacji - notatki, wywiady, zestawienia, wyciągi czy rysunki. Posługiwanie się tymi materiałami stanowiło podstawę do dalszych opracowań. Ważne było zachowanie reguły bezpośredniego związku zapisu z badaną rzeczywistością. Badacze korzystali z materiałów sporządzonych przez siebie oraz dostarczonych przez kolegów, używanie tych drugich sprzyjało rozluźnieniu związku z informatorami. Mając przed sobą cudze dokumenty, nie dysponowali wiedzą na temat rozmówców popartą bezpośrednim kontaktem. Co najwyżej sprowadzała się ona do wyobrażenia opartego na metrykach i indeksach, te zaś „produkują prawdę pod nieobecność" (Foucault 1998: 38).

Charakter indeksów etnograficznych oddają trzy aspekty. Po pierwsze, w zasadniczej mierze opis stanowił pochodną procedury zbierania danych. W tym świetle dokument jest zarazem celem badań oraz ich skutkiem ubocznym. Jako zapisana kartka papieru posiada: 1) materialny wymiar poświadczający, że spotkanie rzeczywiście miało miejsce; ponadto 2) wytwarza efekt widzialności tego, czego dotyczy, tego, do czego/kogo się odnosi. Jak sugeruje John Maxwell Coetzee (2009: 36), istnienie indeksów, tabel czy rubryk wyposażyło badaczy w narzędzia pozwalające mierzyć zjawiska, dostarczyło kategorii, poprzez które rzeczywistość powinna być opisywana. Odpytywana według kwestionariusza osoba stawała się głównym źródłem materiału służącego do wypełniania dys- 
kursu, przez co daje się ją rozbierać na części i na powrót składać, włączając przy tym „w układ ścisłej podległości” (Foucault 1998: 133-134).

Po drugie, każdemu dokumentowi przypisywano określone miejsce w zasobie archiwalnym. Poprzez nadanie sygnatury oraz opracowanie merytoryczne polegające na skatalogowaniu wątków pojawiających się w treści materiału jego zawartość zyskiwała dodatkowe znaczenie, będąc częścią większej całości zbioru danych. W warunkach archiwum aparatura pisania pozwala na dowolne zestawianie elementów (Foucault 1998: 186).

Po trzecie, w rozumieniu Foucaultowskim prowadzenie badań terenowych odpowiadało egzaminowi rozumianemu jako szczególne uprawnienie. Odnosiło bowiem określoną grupę uprzywilejowanych osób - w tym przypadku etnografów - względem innych, dając im możliwość domagania się cudzej wiedzy, wydobywania jej i włączania w obręb własnego specjalistycznego dyskursu. Co istotne, skutkowało to indywidualizującym (Zielinski 2010: 283) wyodrębnianiem tego, co bliskie i poznawane. Fragmenty badanej rzeczywistości stawały się w ten sposób bardziej wyraźne. Identyfikacja prowadzi bowiem do ustanowienia tego, co jednostkowe (Sekula 2010: 165), czyniąc z każdego badanego „przypadek" (Foucault 1998: 186). Pozwalało to jednocześnie na ich wydzielenie $\mathrm{z}$ kontekstu, a w dalszej kolejności na typizację sprowadzającą tych ludzi do postaci zestawu interesujących cech. Rozłożenie na części skutkuje „włączeniem indywidualności w obręb dokumentacji" (Foucault 1998: 184), a w dalszej kolejności - pozwala na operowanie tak wytworzonymi zespołami danych mającymi śladowy związek z pierwotnym źródłem informacji, czyli rozmówcami. Logikę sporządzania i operowania indeksami etnograficznymi można podsumować ich wybiórczością.

\section{Status rozmówców a kształtowanie się paradygmatu badań etnograficznych}

Historię etnografii, tak jak właściwie historię każdej innej dyscypliny, da się opisać jako powolny proces wyodrębniania i kodyfikowania metodologii postępowania naukowego. Wiąże się to $\mathrm{z}$ trybem dostarczania oraz uwierzytelniania danych mających stanowić podstawę wywodu czy rozważań teoretycznych. Na gruncie antropologii materiału takiego poszukiwano $w$ terenie, to jest $u$ ludu wiejskiego bądź wśród "dzikich" plemion. Z początku dostarczaniem go zajmowali się misjonarze, podróżnicy oraz rozmaici amatorzy i fascynaci. Kierowali się oni mniej lub bardziej zbornymi wskazówkami dostępnymi w publikowanych w XIX w. przewodnikach, instruktarzach, ankietach czy apelach i odezwach nawołujących do zbierania "rzeczy ludowych”. W dobie kształtowania się zrębów instytucjonalnej odrębności etnologii, a zatem wąskiego jeszcze grona specjalistów z tego zakresu, większości materiałów dostarczali właśnie amatorzy, przesyłając uczonym opisy zwyczajów, języka czy obrzędów. 
Przełom wieków wraz $\mathrm{z}$ postępującą profesjonalizacją przyniósł $\mathrm{w}$ tym względzie szereg zmian. Amatorów zaczęli stopniowo wypierać fachowcy mający zarówno zaplecze $\mathrm{w}$ postaci kierunkowego wykształcenia akademickiego, jak i bagaż doświadczeń poparty już prowadzonymi badaniami terenowymi. Przypadkowo czynione opisy zaczęły uzupełniać, a następnie zastępować materiały sporządzane w sposób systematyczny i planowy. Warunkiem stało się czerpanie wiedzy z autopsji, bez konieczności posiłkowania się pośrednikami (por. Posern-Zieliński 1973; Jasiewicz 2011).

Przemiany te znalazły odzwierciedlenie w narzędziach, jakimi są kwestionariusze i ankiety. $Z$ początku stanowiły one przeglądowe, acz zwięzłe, zestawienia tematów, które pozwoliłyby na możliwie pełne opisanie danej kultury czy społeczności, co z kolei wiązało się z teoriami ewolucjonizmu i dyfuzjonizmu. Publikowano je na łamach prasy i magazynów o charakterze krajo- i ludoznawczym, takich jak „Wisła”, "Lud", „Orli Lot". Nierzadko miały formę druków ulotnych. Wraz z ewolucją myśli teoretycznej w etnologii zmianie uległo przeznaczenie kwestionariuszy. Prócz oględnej informacji o celu i zadaniu, jakie ma spełnić dana "akcja” (por. Znamierowska-Prüfferowa 1948: 1-9), zaczęto je opatrywać obszerniejszymi akapitami, a później częściami dotyczącymi prawidłowego postępowania badawczego. Ważne, że instrukcje te nie były już kierowane do amatorów, lecz do profesjonalistów, co w przypadku badań zespołowych pozwalało na zbieranie spójnego korpusu danych. Specjalizacja pociągnęła za sobą także uszczegółowienie $\mathrm{w}$ zakresie treściowym. Zagadnienia ogólne zaczęły zastępować ujęcia problemowe, skupiające uwagę badaczy tylko na wybranych kwestiach, a nie jak to było wcześniej - całości kultury. Zmiana zakresu spowodowała zmianę liczby i szczegółowości pytań. Kwestionariusze przyjęły postać rozbudowanych broszur, książeczek lub plików kart z wytycznymi. Był to proces paralelny $\mathrm{z}$ pojawianiem się nowych teorii $\mathrm{w}$ antropologii, takich jak choćby funkcjonalizm czy strukturalizm. W ich obliczu szczegóły $\mathrm{z}$ terenu nabrały nowego znaczenia. Rozbudowanie wachlarza dostępnych teorii zostało umożliwione przez zredukowanie uczestnictwa amatorów i zastępowanie ich zawodowymi etnografami $w$ procesie badawczym. Sukcesywne zwiększanie liczby „wykwalifikowanych etnografów, biorących pełną odpowiedzialność za zebrany materiał" (Sprawozdanie 1954: 1259) doprowadziło do zmiany postrzegania samego materiału oraz bezpośrednich depozytariuszy badanych kultur.

Zmiana optyki z ujęć płaszczyznowych na rzecz pogłębionej perspektywy, a także zmiana sposobu prowadzenia samych badań wpłynęły na przekształcenie sposobu traktowania rozmówców. Oddają to choćby subtelności językowe; w miejsce uprzedniego „zbierania" pojawiło się „badanie”. Pojedynczych gospodarzy, włościan czy często anonimowych chłopów zastąpili znani z imienia i nazwiska informatorzy. Relacje z nimi nabrały jednak bardziej technicznego i przelotnego wymiaru. W Polsce ze względów finansowych, organizacyjnych, instytucjonalnych, czasowych, tematycznych czy politycznych ${ }^{3}$ stosunkowo

\footnotetext{
${ }^{3}$ Szerzej na temat tych względów w: Czachowski, Słomska-Nowak 2011: 8; Wróblewski 2014.
} 


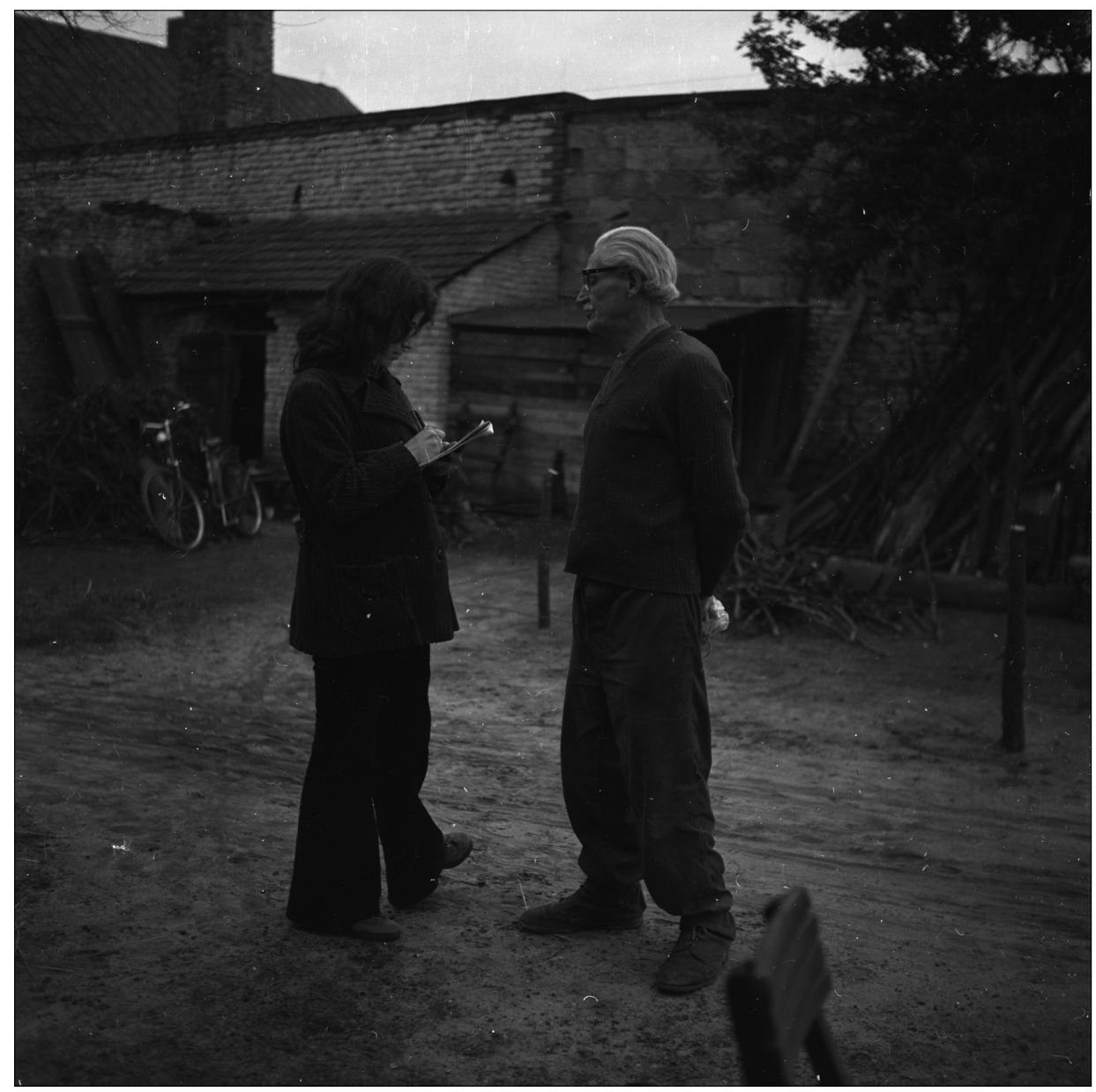

Fot. 1. Wywiad z rzeźbiarzem W. Czerwińskim

Fot. Marek Gawęcki (Cyfrowe Archiwum im. Józefa Burszty CC-BY-SA 3.0 PL)

rzadko prowadzono długotrwałe badania stacjonarne. Opierano się raczej na sezonowych - jak je podówczas określano - „penetracjach” czy „lustracjach terenu" (MET/MZP-II-Kukier Ryszard), realizowanych zespołowo, co po części wynikało z obciążeń powodowanych obowiązkami służbowymi oraz warunkami klimatycznymi (por. Znamierowska-Prüfferowa 1932: 10 i 1959: 23). Podejście to na długi czas stało się podstawowym modelem uprawiania etnografii w Polsce po 1945 r. Ze względu na ograniczoną dostępność i tak nielicznych wtedy i drogich w utrzymaniu aparatów fotograficznych, magnetofonów czy mających się dopiero pojawić dyktafonów posiłkowano się przede wszystkim odręcznymi notatkami. Wraz z koniecznością posługiwania się rozbudowanymi kwestionariuszami determinowało to sposób postępowania badawczego, sprowadzającego się przede wszystkim do lakonicznej rejestracji występowania 
określonego zjawiska bądź faktu. Wychwycenie i utrwalenie informacji zależało zatem od umiejętności badacza, biegłości notowania oraz pamięci. W tych warunkach wiadomości o kontekście rozmowy oraz relacjonowanie cudzych wypowiedzi przybierały przeważnie postać mowy zależnej. W oficjalnym dyskursie rozmówcom rzadko kiedy poświęcano uwagę, jeśli o nich wspominano, to zazwyczaj ogólnie - "rozpytywać się o nie wieśniaków sędziwych" (Moszyński 1925: 29) albo generalizując na temat zbiorowości:

zebrano materjał od przeszło 200 wieśniaków, przeważnie starców. Na Białorusi pytano Białorusinów, na obszarach małoruskich i mieszanych małorusko-polskich wyłącznie Małorusinów (Ukraińców). (Moszyński, Klimaszewska 1932, karta „Przedmowa”: 3)

Rzadko kiedy powoływano się z imiennym wskazaniem na informacje od nich zaczerpnięte, jeśli wyrażano zainteresowanie losem rozmówców, to zazwyczaj na łamach korespondencji (np. prowadzona przez Kazimierę Zawistowicz-Adamską wymiana listów z zaborowianami trwała niemal do jej śmierci; MAE/ KZA 81) bądź innych dokumentów nie przeznaczonych do druku. Zainteresowanie badanymi osobami miało marginalny charakter, poświęcano im uwagę o tyle, o ile pozwalało to na potwierdzenie występowania danego zjawiska przy określeniu jego zasięgu, tego, czy był on "krawędziowy”, "przerywany” bądź „dwuskrzydłowy” (Moszyński, Klimaszewska 1932). Ewentualne wzmianki na temat ludzi spotkanych $\mathrm{w}$ terenie przybierały zatem postać spisów informatorów zamieszczanych na końcu prac lub wyrazów wdzięczności dla tych

których spotykamy na wsi, a których nazwisk niepodobna wymienić, za ich gościnność, ofiarność i poświęcane nam wielu godzin czasu na długie i męczące wywiady, za zaufanie, jakim nas darzą opowiadając o swoim życiu i pokazując wnętrze swych domostw. (Znamierowska-Prüfferowa 1959: 27)

Wreszcie, informacyjny charakter badań polegających częstokroć na krótkotrwałej obecności w danym miejscu rzadko kiedy sprzyjał zażyłości czy nawiązywaniu długotrwałych relacji, co skutkowało okazjonalnym zainteresowaniem biografiami rozmówców, a także szerszym kontekstem towarzyszącym wywiadom. Kwestie te budziły wiele dyskusji w środowisku samych badaczy. W dobie formowania, a później krzepnięcia paradygmatu etnograficznych badań terenowych lat $50 . \mathrm{XX}$ w. kłopotliwym było nawet określenie trybu i notacji danych. Do form narracyjnych czy obszerniejszych opisów odnoszono się jak do "gadatliwych wywiadów" czy "niepotrzebnego balastu”, w ich miejsce wskazywano raczej większą przydatność notatek syntetycznych opracowywanych według kolejności pytań z kwestionariusza. Zapis ten preferowano, ponieważ zawierał dające się łatwo zestawiać odpowiedzi (Gajkowa 1954). Celem, jaki sobie podówczas stawiano, było bowiem uzyskanie obiektywnego obrazu wsi, co wymagało - przynajmniej deklaratywnego - oddzielenia od subiektywnych opinii informatorów. Wydaje się, że to podejście mogło mieć wpływ na instru- 
mentalizację ich roli w badaniach. Przejście od opisu czynionego przez jednego autora materiałów na rzecz zbioru danych dostarczanego przez wielu badaczy, zawierającego przy tym wycinkowe wzmianki o informatorach, przekładało się na postępującą anonimizację rozmówców. Wiedzę na ich temat czerpano już nie z obszernych opisów, lecz z tabel, metryk i rubryk, na które zostali rozpisani. Ów skonwencjonalizowany sposób przedstawiania polegał przede wszystkim na esencjalizacji i enumeracji (Appadurai 2005: 170). Rozmówców - czy raczej wyimkowe i schematyczne parametry powiązane z nimi - zrównano z danymi na temat sierpów, chomąt czy bron. Sprowadzenie ich do postaci dającego się dowolnie zestawiać i porównywać rejestru pozwoliło wkomponować informacje o respondentach do większego systemu porządkowania wiedzy, jakim jest archiwum. Dopomogło to w "pozbyciu się ciężaru osoby” (Agamben 2010: 63), a zatem zatarciu cech dystynktywnych, charakterologicznych i osobniczych pozwalających na wyróżnienie i określenie tożsamości. Ograniczając związek z danymi, których źródło stanowili, doprowadzono nie tylko do swoistego zatarcia śladów tego związku, lecz również do programowej redukcji ich podmiotowości. Koherentny obraz konkretnych osób zastąpiły parametry i wskaźniki wyodrębniane na podstawie utylitarnych kryteriów (por. Sekula 2010; Zielinski 2010).

\section{Instrukcje i wytyczne}

Zanim zostanie omówiona treść wybranych indeksów, wypada poświęcić nieco uwagi zaleceniom co do poprawności ich sporządzania. I tak, w pełniącej rolę podręcznika akademickiego Metodyce etnograficznych badań terenowych Bronisławy Kopczyńskiej-Jaworskiej znaleźć można wskazanie co do konieczności zaopatrywania wywiadu w "metrykę", "charakterystykę informatora" oraz informację o „okolicznościach prowadzenia wywiadu”. Pierwsza z wymienionych miała zawierać następujące wskazania: nazwę miejscowości, imię i nazwisko informatora, wiek $\mathrm{z}$ datą i miejscem urodzenia, zawód i wykształcenie, nazwisko osoby sporządzającej notatkę, datę przeprowadzenia wywiadu, zakres tematyczny materiału (nagłówek). Uszczegółowieniem powyższych "danych" miały być informacje pozyskiwane $\mathrm{w}$ trakcie obserwacji prowadzonej nieustannie podczas wywiadu, a zawierane właśnie $\mathrm{w}$ charakterystyce. Jak pisze Kopczyńska-Jaworska, składają się na nią: „obserwacje dotyczące stosunków rodzinnych informatora, jego stopy życiowej, ogólnego wyglądu domu czy obejścia oraz uzyskane przez badacza $\mathrm{w}$ trakcie prowadzenia wywiadu dane personalne informatora, które ułatwiają właściwą ocenę uzyskanych wiadomości i odzwierciedlają zarazem postawę społeczną informatora" (Kopczyńska-Jaworska 1971: 73).

Należy podkreślić znaczenie powyższych wytycznych, które, po pierwsze, przydają pracującym $w$ terenie etnografom prawo natychmiastowej (czynionej jeszcze przed transkrypcją) weryfikacji pozyskiwanych materiałów poprzez 
ocenę wiarygodności i przydatności osoby udzielającej informacji. Ten szczególny nacisk kładziony na ocenę danego rozmówcy wynikał z założeń opisanego paradygmatu tworzenia i krytyki źródeł, obligujących badacza do wykluczenia „zniekształceń spowodowanych przez badanego osobnika”, co z kolei miało zapewnić „maksymalną wiarygodność” (Biały, Żarnecka-Biały 1963: 12). Było to tym bardziej istotne, że "przy posługiwaniu się metodą wywiadu, między badaczem a przedmiotem badań pośredniczy informator; on to niejako zastępował badacza, spostrzegając w miejscu i czasie, w których badacz nie mógł być obecny" (Biały, Żarnecka-Biały 1963: 17-18). Pośredniczenie owo, w postaci "relacji składanej badaczowi przez informatora", polegało na postrzeżeniowym procesie poznawczym i jako takie miało narażać tworzony obraz faktów na zniekształcenia, gdy spostrzeżenia te były „źle dokonane, źle przechowane w pamięci, a następnie źle odtworzone" (Biały, Żarnecka-Biały 1963: 17). Należało zatem doprowadzić do zredukowania barier w kontakcie etnografa z badanym faktem. Rozmówca stanowił natomiast mniej lub bardziej doskonały środek do tego celu i - jako narzędzie, które należało umiejętnie wybrać - powinien być w najwyższym stopniu przeźroczysty.

Po drugie, "postawa społeczna informatora” oznaczała nastawienie względem świata otaczającego rozmówcę, zainteresowanie nim lub jego brak. Owa skłonność aktywnego partycypowania mogła się odnosić choćby do uznawania sensowności prowadzonych badań, a zatem przyzwolenia na ich bieg. Ze względu na tematykę poruszaną $\mathrm{w}$ trakcie badań mogła ona także - pośrednio - dotyczyć wątków o charakterze politycznym ${ }^{4}$, w tym stosunku do ustroju, kierunku

\footnotetext{
${ }^{4}$ Bronisława Kopczyńska-Jaworska, komentując pierwotną wersję niniejszego tekstu, podczas dyskusji konferencyjnej dnia 23.04.2010 r., zwracała uwagę (wypowiedź autoryzowana): „To jest problem, zestawienie tekstów z podręcznika i wytycznych Atlasu. Otóż to, co było napisane w Atlasie, usłyszałam po raz pierwszy. Świadczy to o mojej ignorancji, ale Atlasem zbytnio się nie interesowałam. Wobec tego nie wiedziałam, że w Atlasie była taka zapowiedź możliwego wykorzystania wyników badań etnograficznych i co ją spowodowało. (Być może chęć wzbudzenia życzliwości dla prowadzonych prac, podkreślenia możliwości ich praktycznego zastosowania, co mogło prowadzić do otrzymania większych środków na badania). Natomiast muszę przyznać, że użyte - w cytowanym tekście sformułowanie - zalecanie zbierania wiadomości, które pomogą w poznaniu »postawy społecznej informatora «, było sformułowane niefortunnie i mogło sugerować, że chodzi o ustalenie stosunku informatora do politycznej rzeczywistości, co w warunkach ówczesnych mogłoby go narazić na przykre następstwa. Byłaby to nieostrożność ogromna pytać o stosunek do rzeczywistości, do ustroju.... Nie to mieliśmy na myśli... Chodziło nam o »status« społeczny i gospodarczy informatora, o jego pozycję w społeczności badanej! Zwłaszcza, że pracowaliśmy pod kierunkiem osoby starszej i tak doświadczonej w badaniach jak prof. Zawistowicz-Adamska, dla której to miejsce w społeczności było bardzo istotne. Nie mieliśmy nigdy zamiaru badania stosunku informatora do politycznych spraw, również z tego względu, że zdawaliśmy sobie dobrze sprawę, że notując tego rodzaju informacje, narażalibyśmy ludzi, z którymi rozmawiamy. To absolutnie nie mogło mieć miejsca. $Z$ dużym zainteresowaniem wysłuchałam tych współczesnych uwag na te dawne zalecenia, dostrzegłam to niefortunne sformułowanie, dawniej niezauważone, co może wynikało z odcięcia się ówczesnego środowiska etnograficznego od problemów stricte politycznych. Przedmiotem badań była przede wszystkim tematyka, którą dzisiaj się określa
} 
zachodzących zmian czy konkretnych działań podejmowanych przez władze. Nie jest bez znaczenia, że w okresie przymusowej kolektywizacji wsi zapoczątkowanej w Polsce w 1948 r. z ramienia Polskiego Towarzystwa Ludoznawczego prowadzono badania o zasięgu ogólnopolskim mające stanowić podstawę szeregu monografii regionalnych oraz projektowanego Polskiego Atlasu Etnograficznego. Zamierzenia te do początku lat 50 . były subwencjonowane bezpośrednio przez Prezydium Rady Ministrów, a od 1953 r., to jest po kasacji programu monografii, przez Polską Akademię Nauk. Co znamienne, w trakcie badań pilotażowych PAE dotyczących hodowli i rolnictwa w 1952 r. etnografowie mieli za zadanie badać "reprezentacyjne" dla danej grupy "gospodarstwa małorolne, średniorolne i kułackie" (Sprawozdanie 1954: 1266). Oprócz pozyskiwania informacji o technikach uprawy i hodowli, narzędziach czy urodzajności ziemi, dopytywano się o stan i tytuły prawne posiadania, stosunek do ziemi i dobytku przed i po uwłaszczeniu. Zainteresowaniem badaczy cieszyła się także struktura społeczna wsi rozpatrywana przez wzgląd na:

Ilość i wielkość gospodarstw wedle ilości posiadanych hektarów. Podać nazwy i kryteria danych gospodarstw w zależności od a) ilości ziemi uprawnej, jej jakości, poziomu gospodarki i wydajności; b) od obfitości i jakości inwentarza; c) od ilości stałych i czasowych najmitów, członków dalszej rodziny itp. W szczególności zwrócić uwagę na ilość i jakość posiadanych narzędzi pracy, na zyski osiągane przez ich wynajmowanie oraz na zyski, płynące $\mathrm{z}$ wynajmu zwierząt pociągowych. Uwzględnić prestiż i stanowisko we wsi w zależności od sytuacji gospodarczej danej jednostki (opracować możliwie krótko, ale ściśle, w czym się ten prestiż przejawia i na czym to stanowisko polega). (Sprawozdanie 1954: 1261)

Uwikłanie, zarówno etnografa, jak i jego rozmówców, w polityczne oceny bieżących spraw uwidacznia także relacja Bożeny Stelmachowskiej z Ziem Odzyskanych:

stwierdziłam wszędzie, że ludność polska ośrodków wiejskich ma pozytywne ustosunkowanie do rzeczywistości współczesnej, że na każdym odcinku życia dąży do postępu, że postęp ten rozumie, a co więcej odnosi się do niego w sposób emocjonalny. (...) Nowi osadnicy, rekrutujący się z różnych stron kraju, z Wielkopolski, Kaszub, z Małopolski wschodniej, zza Buga w najszerszym tego określenia ujęciu byli wszyscy zgodni $\mathrm{w}$ jednym: pragną gospodarować $\mathrm{w}$ swoim nowym regionie w sposób nowoczesny i doskonale rozumieją jak ten cel osiągnąć. Zapy-

\footnotetext{
jako antropologię gospodarczą, były to badania historii kultury materialnej, badania dotyczące tradycji i zmian gospodarczych. Rzadko były podejmowane badania dotyczące tożsamości czy problemów etnicznych, które również były objęte milczeniem politycznym. I wobec tego, takiego typu badań raczej nie należałoby prowadzić. No, był to na pewno pewien odruch samoobrony. Przez to, że etnografia nie wchodziła w tematykę bardzo zaangażowaną społecznie i politycznie, była... no, nie budziła zainteresowania czynników politycznych. I myśmy $\mathrm{w}$ takiej niszy społeczno-politycznej pracowali. Teraz słuchając uwag referenta zdałam sobie sprawę, że z dzisiejszej perspektywy patrząc na pewne uwagi (w tym przypadku jeszcze błędne sformułowanie), można wysnuć bardzo krytyczne wnioski".
} 
tywani o dawne narzędzia pracy odnosili się do drewnianego sprzętu z niechęcią i lekceważeniem. Już sam wyraz ,socha” budził bardzo żywą, negatywną reakcję, jako symbol wstecznictwa. (...) Oglądałam pokazywane mi z dumą najnowsze pługi, brony, siewniki, słuchałam wesołego warkotu młockarni mechanicznych pędzonych prądem elektrycznym i słuchałam zwierzeń starych ludzi, którzy opowiadali mi o tym ile to długich zim spędzili z cepami na klepisku, aby zarobić ów jedenasty korzec żyta na chleb dla głodujących dzieci. (Stelmachowska 1953: 8)

Z dzisiejszej perspektywy trudno ocenić, na ile głosy tego rodzaju wynikały z rzeczywistego poparcia dla idei socjalistycznych, koniunkturalizmu bądź potrzeby asekuracji i konieczności kluczenia między wyznawanymi poglądami a panującą "poprawnością polityczną". Jak bowiem w takim razie traktować jedno z powojennych założeń PEA mówiące o praktycznym wymiarze badań, które nie tylko mają „utrwalić ginące formy zjawisk kultury ludowej, ale będą podstawą dla planowania $\mathrm{w}$ dziedzinie budownictwa, rolnictwa, szkolnictwa i oświaty” (Ankieta nr 1-2 1948: II)? Było to tym ważniejsze, że „podejmując program oddziaływania etnograf musi przede wszystkim przeprowadzić analizę współczesności" (Stelmachowska 1946: 9), to zaś wiązano z odbudową i planowaniem rozwoju kraju. Być może taka nowomowa była wymogiem pozwalającym sprawnie funkcjonować etnografii poprzez uzasadnianie konieczności prowadzenia właśnie tak sprofilowanych badań. Niemniej wart zastanowienia jest ów dyskretny mariaż z władzą. Należy podkreślić, że uroszczenie do pożyteczności „służby społecznej” stale towarzyszyło tej dyscyplinie w poprzednim ustroju politycznym, czego przykładem mogą być liczne głosy wyrażone na kartach Funkcji spotecznych etnologii (Jasiewicz 1979).

Co znamienne, autorka przywołanego skryptu systematyzuje rozwiązania wypracowane na drodze powojennej praktyki terenowej rozmaitych ośrodków badawczych z obszaru całego kraju. Nie bez znaczenia pozostaje fakt, iż do czasu publikacji Metodyki nie istniała w polskim piśmiennictwie metodologicznym zwarta regulacja dotycząca indeksów etnograficznych. Kopczyńska-Jaworska, kierując się wzrastającym zapotrzebowaniem ze strony dydaktyki akademickiej, skodyfikowała dostępną podówczas wiedzę. Składały się na nią głównie źródła takie jak: 1) instrukcje badawcze zawarte w kwestionariuszach, 2) druki ulotne w postaci maszynopisów zawierających regulaminy czy wskazówki na temat postępowania w terenie, sama 3) praktyka badawcza oraz 4) bezpośredni przekaz umiejętności w postaci wywiadów pokazowych ${ }^{5}$ (Kutrzeba-Pojnarowa

\footnotetext{
${ }^{5}$ "Grupę szkoleniową podzieloną na zespoły instruktor zapozna z techniką pracy terenowej, mianowicie objaśni studentów jak powinien zachowywać się badacz na wsi, jakich ma dobierać informatorów i w jaki sposób przeprowadzać z nimi wywiad i prowadzić zapiski. Instruktor również zapozna studentów jak się opracowuje kwestionariusz i jak się go wypełnia. (...) Instruktorzy podzielą grupę szkoleniową na zespoły, przydzielą im opiekunów, rozdadzą tematy samodzielnych prac terenowych i wprowadzą studentów do podstawowych technik pracy terenowej. Opiekunowie zespołów pomogą studentom opracować kwestionariusze, przepracują z nimi tematykę przydzieloną i przygotują ich do samodzielnego poruszania się i pracy w terenie" (Instrukcja 1954: 6-7, 12).
} 
1955: 227, 231), przeprowadzanych na przykład w ramach rokrocznie organizowanych Międzyuczelnianych Obozów Etnograficznych (1952-1985).

Do ustabilizowania się kształtu oraz zawartości charakterystyk informatora w znacznej mierze przyczyniła się Kazimiera Zawistowicz-Adamska. Powierzono jej zadanie sporządzenia projektu instrukcji dla badania ogólnej charakterystyki wsi oraz rzeczonych charakterystyk informatorów, które później jako części "A" i „B" weszły w skład kwestionariuszy publikowanych w ramach Polskiego Atlasu Etnograficznego, a tym samym były kolportowane pośród wszystkich ówczesnych członków środowiska etnograficznego. Nie wiadomo, jaki projekt ostatecznie przedłożyła komitetowi redakcyjnemu Zawistowicz-Adamska, można jednak przypuszczać, iż był on bliski jej postulatom traktowania rozmówców wyłożonym na kartach Społeczności wiejskiej (Zawistowicz-Adamska 1948: 127-138). Nie zmienia to faktu, iż sformułowany szablon ma raczej schematyczny układ i takie też generalnie są jego realizacje terenowe. Dla uzyskanego efektu znaczącym może być również, iż konsultantem tej właśnie części instrukcji pomieszczonych w kwestionariuszach był Kazimierz Moszyński (Judenko 1953a: 4), którego oficjalne stanowisko w tym względzie było niezwykle formalne i techniczne. Co więcej, w kwestionariuszach można znaleźć wzmiankę o przygotowaniu instrukcji sporządzania obu charakterystyk w opracowaniu Komitetu Redakcyjnego PAE „na podstawie projektu” dostarczonego przez Zawistowicz-Adamską (Kwestionariusz I 1953: 1), a zatem efekt końcowy był raczej wynikiem konsensusu bądź został podyktowany praktycznością woli grupowej, aniżeli stanowił konsekwentną realizacją wizji jednego autora. Czego dotyczyły zmiany - nie wiadomo.

We wspomnianych kwestionariuszach ustalono schemat opisu informatorów według następujących punktów:

1. Nazwisko i imię informatora.

2. Miejsce i data urodzenia.

3. Od jakiego czasu przebywa w tej wsi.

4. Gdzie przebywał przez dłuższy czas poza wsią, w której się urodził lub w której obecnie mieszka. Gdzie mieszkał w 1939 roku.

5. Wykształcenie.

6. Czy poza rolnictwem oddaje się jakiejś pracy zawodowej; ewentualnie podać umiejętności specjalne.

7. Główna podstawa utrzymania, poboczne źródła dochodu.

8. Czy chętnie, sumiennie i inteligentnie udzielał odpowiedzi (Kwestionariusz II 1954: 17).

Zawartość i układ charakterystyki informatora podawane w większości wywiadów terenowych ustabilizowały się właśnie za przyczyną kwestionariuszy publikowanych na potrzeby atlasu etnograficznego. Stanowiły one punkt odniesienia przy formułowaniu własnych kwestionariuszy problemowych ${ }^{6}$, jed-

\footnotetext{
${ }^{6}$ Tematyczny i problemowy przegląd kwestionariuszy z krótkim rysem historycznym w: Kamocki 1953.
} 
nocześnie dostarczając gotowych rozwiązań co do stałych części, które winny znaleźć się w każdym kwestionariuszu. Dodatkowo, dopóki nie opracowano publikacji z zakresu metodyki badań terenowych, kwestionariusze atlasowe pełniły rolę pomocy dydaktycznej podczas MOE (Kutrzeba-Pojnarowa 1955: 232), zarówno ze względu na zbieżność poruszanej problematyki badawczej, jak też szereg szczegółowych rad dotyczących postępowania w terenie czy prowadzenia wywiadów (wskazówki te umieszczano w kilkunastostronicowym wstępie). Co ważne, akurat w trakcie pierwszych MOE kształciła się większość późniejszej, powojennej kadry uniwersyteckiej z zakresu etnografii. Dodatkowo funkcję instruktorów pełnili przedstawiciele katedr etnografii z Warszawy, Krakowa, Poznania (później także z Wrocławia i Łodzi). Część z tych osób brała udział zarówno w samych badaniach atlasowych, jak i w posiedzeniach Komitetu Redakcyjnego PAE. Ciało to walnie przyczyniło się do ujednolicenia procedury sporządzania notatek i materiałów terenowych. Uznano, że powszechnie obowiązującym powinien być format kart archiwalnych, co miało ułatwić korzystanie z materiałów (Judenko 1953b: 10). Dało to podstawę do ujednolicenia w skali całego kraju rozwiązań formalnych związanych z archiwistyką etnograficzną i sposobem rejestracji źródeł.

Wracając do treści „"charakterystyki”, miała ona również zawierać informacje o pochodzeniu rodziny, jej losach i koligacjach; określać położenie socjalne i majątkowe, źródła utrzymania oraz zarobki dodatkowe; oceniać ogólny poziom inteligencji, uwzględniając: wykształcenie, odbyte kursy, oczytanie, dostęp do radia i telewizji. Ponadto, odnosząc się do udziału indagowanego w życiu społecznym wsi, etnograf nie może zapomnieć o nakreśleniu stosunku informatora "do zachodzących przemian”, powinno się również uwzględnić publiczną opinię o informatorze i jego rodzinie (Kopczyńska-Jaworska 1971: 74). Trzecia z notatek, będąca uzupełnieniem poprzednich, a odnosząca się do okoliczności wywiadu, miałaby zawierać informację o sposobie nawiązania rozmowy i warunkach, w jakich była ona prowadzona. Co ważniejsze, jej stały a niezbędny element stanowiły uwagi dotyczące stosunku informatora do prowadzonej indagacji. Wobec tego należało określić, jak chętnie udzielał on informacji, czy rzeczowo odpowiadał, czy stawiał opór, a jeżeli tak, to co mogło nim powodować i przy jakich pytaniach.

Praktyka sporządzania takich notatek, w świetle materiałów archiwalnych, okazuje się procedurą optymalizowaną przez samych badaczy, którzy trzy wskazywane przez Kopczyńską-Jaworską kategorie analityczne sprowadzali najczęściej do jednego zapisu, pozostawiając przy tym szkieletową metrykę na każdej stronie. Wobec tego już bez zbędnego ich wyróżniania będzie się tutaj mówić o indeksach etnograficznych, mając w pamięci szczególną uwagę względem tych części, które zakładają prawo, a zarazem obowiązek opisu napotykanej przez etnografa osoby. Prawo to bowiem implikuje ocenę drugiego człowieka podług doraźnych, interesownych i z gruntu subiektywnych kategorii. Warto podkreślić, że ocena ta była czyniona $\mathrm{w}$ ramach, i na mocy, autorytetu nauki. Mimochodem tę kwestię naświetliła Jadwiga Klimaszewska, pisząc we 
wstępnym instruktarzu do jednego z kwestionariuszy przeznaczonych zarówno dla laików, jak i profesjonalnych etnografów, iż dane tego typu powinna zawierać "każda notatka, żeby miała wartość naukową" (Klimaszewska 1971: 3). W stwierdzeniu tym ujawnia się obecność obowiązującego ówcześnie pozytywistycznego paradygmatu nauki. Tym samym powojenna etnografia stanowiła kontynuację XIX-wiecznego ludoznawstwa, toteż oczekiwano, że w swej metodologii będzie ona naśladować standardy typowe dla przyrodoznawstwa. Jak wskazuje Jerzy Damrosz, powojenny proces homogenizacji podstaw nauk wokół idei marksistowskich w przypadku etnografii doprowadził do skanalizowania poruszanej przez nią tematyki przede wszystkim do „ludowości” (Damrosz 1996: 30-38).

\section{Indeksy etnograficzne}

Jak wiadomo, prowadzenie poszukiwań etnograficznych wiąże się częstokroć z dużym wysiłkiem ze strony samego badacza. Obecność w obcym miejscu, presja czasu, jak również konieczność wywiązania się z zawodowych zobowiązań stanowią charakterystyczną cechę tego rodzaju pracy, która nie może się powieść bez pozyskania współpracy rozmówców. W tym celu wykorzystuje się najczęściej autorytet związany z instytucją, jaką jest uniwersytet, lub sam fakt prowadzenia działalności naukowej. One to, jako uwierzytelnienie, wraz z umiejętnościami komunikacji interpersonalnej stanowią zaczątek, dzięki któremu staje się możliwy wywiad wykorzystujący kapitał społeczny, jakim jest zaufanie. Może świadczyć o tym następująca relacja: „Informator początkowo niechętny, jednak po kilku rozmowach znacznie zmienił się na korzyść. Nie szczędził też później trudu i wysiłku, aby dokładnie odpowiedzieć na pytania, starając się je praktycznie zobrazować" (PAN 478/452). Gdy interlokutor zaufa, staje się nie tylko pomocny i uczynny, ale - jak relacjonuje etnograf - „wykazuje zrozumienie dla pracy badacza" (PAN 478/450). Jeśli dostatecznie mocno zinternalizuje przydaną mu rolę, po odbytej rozmowie badacz zapisze skrzętnie: „misję swą spełniał bardzo poważnie" (UJ 7856/65).

Nie zawsze jednak rozmówcy byli tak spolegliwi, jak by sobie tego życzyli etnografowie, którzy często spotykali się z niechęcią lub otwartą wrogością i jako obcy byli traktowani podejrzliwie. Wszak nie wiadomo było, kogo tak naprawdę reprezentują. Lustrowanie wsi bądź poszczególnych zagród na równi z czynnością spisywania musiało budzić obawy, czy nie są to aby urzędnicy, czy komu nie grozi „domiar”. Ponadto badacze nachodzący ludność w okresie letnim mogli być postrzegani jako ktoś przeszkadzający podczas prac $\mathrm{w}$ polu, co spotykało się z zarzutami „zabierania czasu ludziom” (Gajkowa 1954: 1273). Trudności pracy tak relacjonowała Bożena Stelmachowska:

Niektórzy z nich objaśniają nas bardzo życzliwie i nie szczędzą długich godzin, aby odpowiedzieć na owych sakramentalnych 130 pytań, pozytywnie, czy nega- 
tywnie, ale zawsze sumiennie. Są natomiast informatorzy, a może przede wszystkim informatorki widzące w zapytanych wsteczność, brak postępu, na który są nastawieni - wybuchają niekiedy niepohamowaną złością, gdy mają odpowiedzieć jak np. pewna kułaczka w Krąpiewie na temat zacofanego sposobu gospodarowania. Wtenczas badacz jest w trudnym położeniu, gdy go gospodyni odsyła "do szkoły" aby się tam nauczył historii kultury. (Stelmachowska 1955: 5)

Wobec powyższego warto zadać sobie pytanie o status „niewinnych” procedur związanych z postępowaniem badawczym przybliżonych powyżej. Po zakończeniu wywiadu, w zależności od nabytego warsztatu i zaleceń kwestionariusza albo przyjętej metodologii, zwykło się w zapisie materiału umieszczać stosowne indeksy, względem których można żywić przeświadczenie, iż mają one status czysto informacyjny. Jednakże nakreślona sytuacja zdaje się przedstawiać zgoła inaczej przez wzgląd na rzeczywistą zawartość samych indeksów. Ich sporządzanie wiązało się z wykorzystywaniem uprzywilejowanej pozycji badacza. W notatkach zawierano oceny poszczególnych rozmówców, najczęściej bez ich wiedzy, zgody czy pełnej świadomości celu, jakiemu ma służyć zbieranie tych danych. Prowadziło to do wytworzenia asymetrycznej zależności: reprezentanci świata nauki obrazują i umiejscawiają przedmiot swojego badania, ów zaś nie czyni nic podobnego (Latour 2012: 229). Zarówno sam fakt sporządzania indeksu - wymaganie takiego prawa, jak też dostępność indeksów dla innych badaczy skłania do refleksji o dyskursywnym ograniczeniu możliwości partnerskiego traktowania rozmówców. Wyznaczono im bowiem określone i - jak się może wydawać - niezmienne miejsce w procedurach etnograficznych. Ten rodzaj esencjalizującego przypisania poddawano już krytyce w łonie rodzimej antropologii. Jednakże dotyczyła ona poziomu reprezentacji - by tak rzec - zewnętrznej, czynionej na użytek czytelników zaznajamianych z końcowym efektem etnografii - publikacjami. Zbigniew Libera (1995) dekonstruował lud jako bohatera XIX-wiecznych monografii etnograficznych, a Marcin Brocki (2011) analizował sposoby prezentowania doświadczeń rozmówców i figuratywne wymiary ich obecności w nowszych tekstach antropologicznych. Nikt jednak nie przyglądał się wewnętrznej logice procedur etnograficznych, a zatem relacjom władzy i dominacji z właściwym im „aparatem racjonalizacji” (Tagg 2011: 44). Jej częścią są właśnie omawiane indeksy oraz sposoby posługiwania się nimi.

Mając w pamięci notatkę Michniowskiej, cytowaną we wstępie niniejszego artykułu, warto przywołać inną, podobną, dotyczącą sześćdziesięcioletniej Rozalii Miś: „,informatorka jest chora, ma bardzo słaby wzrok i od dłuższego czasu nie wychodzi z domu. Informacji udzielała bardzo zwięzłych i jasnych, ale na ogół niechętnie, możliwe, że to z powodu choroby. Informowała o pożywieniu obrzędowym i postnym" (PAN 620/1405). Indeks ów można uznać za szczególnie bliski relacjom, które starają się oddać charakter personalny rozmówcy - to rodzaj mikrobiografii. Zapis, na przekór swemu zasadniczemu celowi, nosi znamiona historii życia, silny egzystencjalny ślad daleki od suchej rejestracji faktów i zmiennych. Każe on spojrzeć na wybrane indeksy, tak jakby z czasem stawa- 
ły się one epitafiami - czymś ku upamiętnieniu mijającej albo też definitywnie i nieodwołalnie minionej obecności. Wracając do powyższej notatki, podkreśla się w niej z jednej strony jakąś słabość czy ułomność, prowokujące życzliwość i sympatię etnografa. $Z$ drugiej nie sposób wymazać aspektu określającego przydatność danej osoby dla prowadzonych badań, za czym przemawia podkreślenie ołówkiem tematów, jakie poruszono w rozmowie, które tym samym będzie można znaleźć $\mathrm{w}$ zgromadzonym materiale. Uwaga nie skupia się ani na rozmówcy, ani na jego życiowych bolączkach, jest on raczej przeźroczystą figurą, środkiem do celu, kimś, kogo się „zdobywa”, a zatem można i bez żalu porzucić.

To uprzedmiotawiające podejście występowało niekiedy w skrajnej postaci, tak jak w poniższej relacji z 1964 r. dotyczącej rolnictwa, gdzie opis osoby (gospodarza i jego rodziny) prowadzony jest z zaiste kuriozalnej perspektywy: „Gospodarstwo: Józef Sikora, [nazwa wsi] Nr. 296. Wielkość gospodarstwa 2,20 ha, odległość od centrum wsi ok. 2 km. Inwentarz żywy: 2 krowy, 2 świnie, 7 kur". I dalej, niemal jak skład inwentarza, członkowie rodziny: „wnuczka 10 lat - (przez cały tydzień sami z dziadkiem na gospodarstwie); córka Helena, 35 lat, robotnica budowlana w Witkowicach CSSR. Przyjeżdża raz na tydzień w piątek wieczór, wyjeżdża w niedzielę wieczór. Na roboty polne bierze bezpłatny urlop z pracy" (PAN 1150/1). Ani słowa o tym, co dzieje się z ojcem dziewczynki albo jak jej na imię i czy się uśmiecha? Wiadomo za to: dziadek, inwentarz, wnuczka i okazjonalnie córka - komplet. Ewidencję kolejnych członków rodziny rozpisuje się jeszcze dokładniej przez pryzmat wykonywanej pracy i majętności. W zasadzie nic $\mathrm{w}$ tym dziwnego, ponieważ sprofilowanie optyki opisu podporządkowano wytycznym i charakterowi kwestionariusza.

Warto poświęcić nieco uwagi konsekwencjom przydanego sobie przez etnografów prawa rozsądzania tego, kto kim jest po stosunkowo krótkotrwałym kontakcie, który ze zrozumiałych względów nie sprzyja nawiązaniu głębokich więzi. I tak, zasadnicza funkcja indeksów sprowadzała się do oceny przydatności rozmówcy. Co zrozumiałe, podczas rozmowy, częstokroć inicjowanej rozmyślnie przez samego badacza, relacje pomiędzy uczestniczącymi w niej stronami ujmowano nad wyraz technicznie. Niemniej zwraca tu uwagę dyskursywna przewaga etnografa nad badanymi, wynikająca z władzy opisywania. Nie idzie zatem o neutralność procesu deskrypcji, a raczej o jego tendencyjność i możliwość wystąpienia przeinaczeń prowadzących wprost do karykaturalności. Poddany badaniu rozmówca, na mocy klasyfikującego opisu (Coetzee 2009: 24-26; Tagg 2011: 49), zostaje zatem sprowadzony do rangi towaru, kogoś, kim można się posłużyć, używając do tego odpowiedniej instrukcji obsługi. Osoba zostaje zredukowana do wymiaru tekstowej reprezentacji (Sekula 2010: 162), zaś konkretne fizyczne ciało przekształcone $w$ inskrypcję. Opis staje się przepisem. Dzięki czemu będą mogli sięgać do niego kolejni badacze. Zasadniczym przeznaczeniem indeksów, przy prowadzeniu wieloletnich badań na jednym obszarze, było bowiem wytypowanie osób, do których powinno się udać w pierwszej kolejności, mając przy tym pewność, iż uzyska się oczekiwane rezultaty bez straty czasu. Owo założenie zyskiwało o wiele większe znaczenie przez wzgląd 
na cykliczność badań albo ewentualną potrzebę weryfikacji materiałów w bliżej nieokreślonym terminie.

$\mathrm{O}$ jednym $\mathrm{z}$ takich powrotów $\mathrm{w}$ teren świadczy indeks sporządzony zielonym atramentem przez Zofię Szrombę-Rysową we wrześniu 1954 r.: "Borosz Rozalia lat 80 Pochodzi z biednej rodziny komorniczej. Pracowała w licznych gospodarstwach górskich. Udzielała informacji ciekawych - pamięć ma b. dobrą i chętnie wspomina dawne czasy. Podarowała ona (do Opola) łyżnik drewniany tzw. »łeżnik « kupiony w Popielowie na jarmarku z 30-ści lat temu" (PAN 620/1398). Kilka lat później, tym samym charakterem pisma, naniesiono łatwo zauważalne poprawki, bo sporządzone niebieskim kolorem. I tak, widnieją $\mathrm{w}$ dokumencie następujące skreślenia i adnotacje: imię zamieniono na "Maria"; dalej, w tej samej linijce enigmatyczne: „Cmentarna” (choć nie ma tu pewności przez wzgląd na krój liter, jak również sens względem całości), a pod spodem „zmarła w 1957 r." Przytoczony cytat uznaje się za symptomatyczny dla oddania indywidualnego charakteru rozmówcy, mógłby on z powodzeniem uchodzić za przyczynek pogłębionej historii życia albo biografii, stanowiąc znamię podejścia akcentującego partnerskie relacje między uczestnikami badania, uogólniając: podejścia personalistycznego (opozycyjnego względem instrumentalnego traktowania napotykanych ludzi). Indeks ów jest zarazem tak świadectwem, jak epitafium. I trzeba dodać - z czasem stanie się - epitafium podwójnym.

Nie sposób przy tym zanegować zasadniczego celu, jaki przyświecał sporządzaniu przywołanego indeksu, którym, jak warto przypomnieć, była użyteczność oraz zagwarantowanie operatywności przyszłych działań. W adnotacjach o tym właśnie charakterze można znaleźć fragmenty równie bezbarwne i oszczędne, jak następujące: „informator chętny, łatwy w pozyskaniu, niezbyt jednak szczegółowy w udzielaniu odpowiedzi” (PAN 478/445). Albo: „Informator gadatliwy, chętny lecz nie bardzo inteligentny" (PAN 478/453). Nie są to wcale notatki odosobnione, nieraz pod im podobnymi podpisywali się uznani badacze, tak jak to miało miejsce $\mathrm{w}$ przypadku seminarium i letnich badań prowadzonych przez Kazimierza Moszyńskiego w 1931 r., poświęconych obrzędowości ludowej. Jadwiga Klimaszewska pisze: „pamięć nienadzwyczajna, umysł jeszcze ruchliwy, inteligencja mała" (UJ 7856/33). Utyskuje Seweryn Udziela: „informator dobry tylko mało sobie przypomina. Dużo trzeba z niego wyciągać" (UJ 7856/21A). Okazuje się, iż można mówić o drugim człowieku w kategorii kodu zero-jedynkowego, bez najmniejszych odcieni szarości, bez życiowych niuansów. Nadto nikogo też nie dziwi, a co gorsza, nie zastawania taki sposób wyrażania wspólny etnograficznemu żargonowi korzystającemu z metaforyki "tajnych służb” (np. „informator”, „wywiad”; Tokarska-Bakir 1995: 19, 21).

W świetle nie tyle zaprezentowanych materiałów, ile raczej tych zapomnianych, które zostały skrzętnie upchane w szafach rozlicznych archiwów, pożądany "informator" to ktoś, kto jest rozmowny, chętny, dużo pamięta, wykazuje inteligencję i zainteresowanie; takiego tylko pragnie się spotkać, w innych zaś wypadkach pozostaje w odwodzie "prawo" etnografa do opuszczenia przegranej 


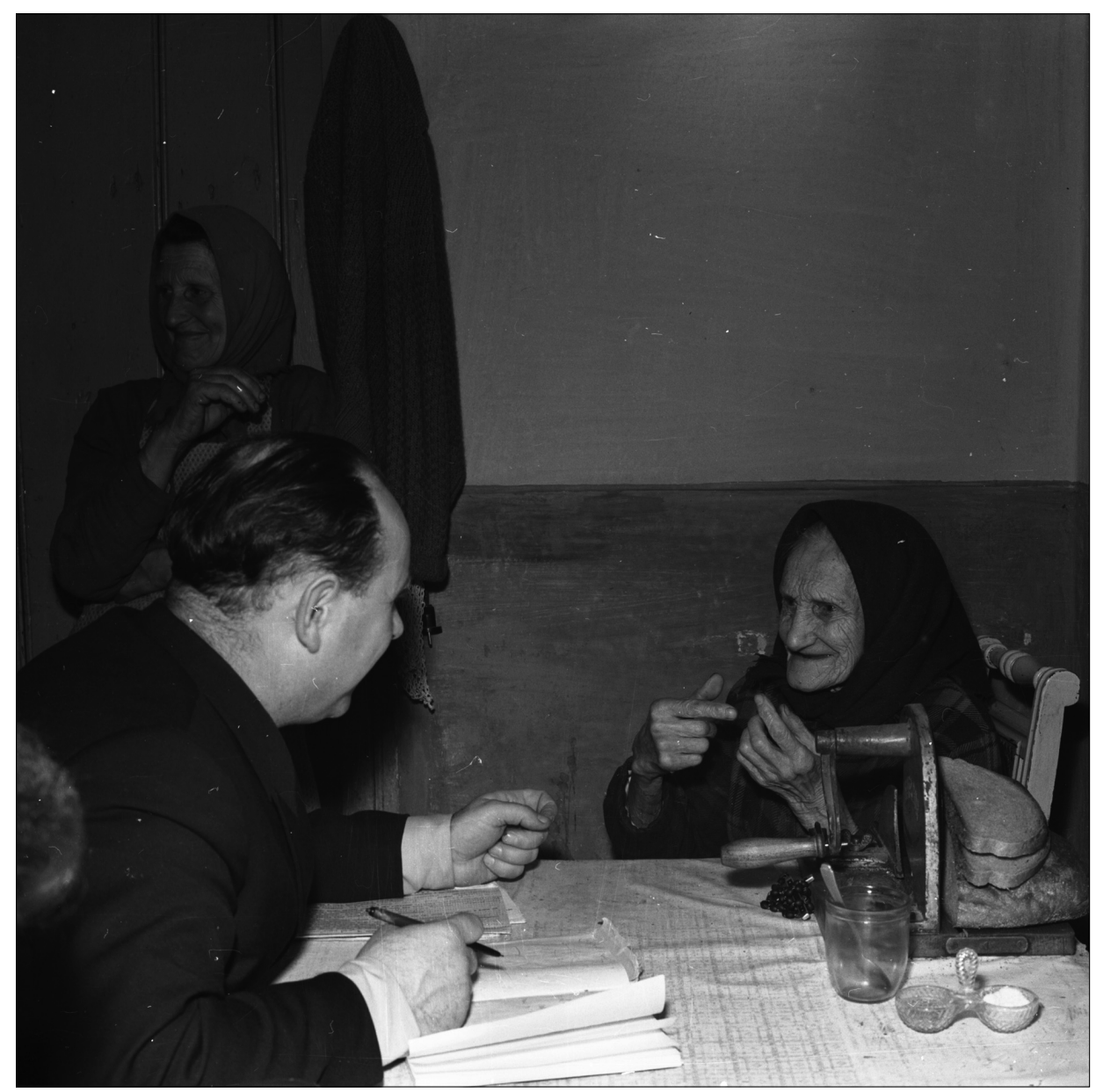

Fot. 2. Dr Walerian Sobisiak podczas wywiadu z informatorką

Fot. Stanisław Kusza (Cyfrowe Archiwum im. Józefa Burszty CC-BY-SA 3.0 PL)

pozycji na froncie badań. W tym względzie zaleca Moszyński: „w razie nieudolności informującego (-cą) zmienić go (ją) jak najrychlej"7 (Moszyński b.d.w.: 2). Bez żalu, bez zobowiązań, historia niebyła - tak jakby spotkanie nigdy nie miało miejsca. Jak relacjonuje Seweryn Udziela, po części kierujący się powyższymi instrukcjami, „do [pytania] O. odpowiadała stara i chora kobieta, bardzo niechętnie, która przy O ucichła. Sołtys przeto zaprowadził mnie do innej urodzonej w Dobrem $4 \mathrm{~km}$ od Makowca (innych starszych nie było) i ta okazała się doskonałą

${ }^{7}$ Co znamienne, w omawianym kwestionariuszu zamieszcza Moszyński następujące wskazanie: „po skończonej indagacji zanotować krótką charakterystykę informatora (-ki), uwzględniając jego pamięć i zachowanie się podczas indagacji” (Moszyński b.d.: 2). Kwestionariusz ten został przedrukowany w Metodyce jako jeden z przykładów formułowania narzędzia badawczego (Kopczyńska-Jaworska 1971: 132). 
i chętną informatorką" (UJ 7856/43B). Prace badawcze można uznać za czynność ścisłego zarachowania, nie tylko pod względem wydobycia czy raczej „wyciągnięcia” pożądanych informacji, ale już na poprzedzającym samą obecność "tam”, nad wyraz instruktywnym poziomie. Oto bowiem Moszyński w innym jeszcze kwestionariuszu oblicza liczbę pytań względem $\mathrm{czasu}^{8}$, w dokumencie pisanym atramentem na spodzie kartki zaznacza drobno ołówkiem - robiąc przypis - że „przeciętna wypada po przeszło 2 minuty na każde pytanie” (Moszyński 1930: 1). Nie więcej. Kategorycznie wykłada wobec tego główną, niekwestionowalną wytyczną: „Absolutnie nie pozwalać odpowiadającemu na zbaczanie od danej kwestii i winien on odpowiadać tylko na pytanie" (Moszyński 1930: 1). W przeświadczeniu etnografa rozmówca zostaje zobligowany do udzielenia odpowiedzi już przez sam autorytet naukowca. Ów miękki przymus wywiązania się obiektu badania z samych jego założeń, naddanych z zewnątrz, spoza świata wsi, przekłada się na sposób traktowania drugiego człowieka. Etnograf nie jest ze swoim rozmówcą ani tym bardziej nie przeżywa ważnych dla niego zjawisk, kierując się właściwymi mu sposobami doświadczania świata. To raczej rodzaj precyzyjnej operacji wojskowej polegającej na błyskawicznym desancie, wykonaniu zadania i równie szybkim powrocie. Przy takiej (nieco przerysowanej) organizacji badań pozostaje niewielki margines swobody. Decyzje podejmuje się szybko i równie szybko ocenia człowieka. $W$ tym względzie możliwe są tylko dwa rozsądzenia: dowartościowujące i deprecjonujące. $W$ pierwszym przypadku za opisem stoi założenie, iż ci, którzy pomagają i są przydatni, to ludzie dobrzy, tych ocenia się pozytywnie. Pozostali stanowią przeszkodę, ponieważ błędna ocena albo skupienie na nich uwagi oznaczałyby stratę cennego czasu. Nie dość, że są nieużyteczni, to jeszcze stanowią zawadę.

Warto również zwrócić uwagę na wymiar emocjonalny czynionych ocen. I tak, możliwe jest wskazanie: „Kokot Piotr, gbur” (PAN 478/445) albo upodlające: „inteligencja mizerna” (UJ 7856/74), "obiekt b. marny” (UJ 7856/19A), „Średniej orjentacji" (UJ 7856/40), „tępy i roztargniony" (PAE S.21/22 P.34 p.IX), "średnio inteligentny (trochę głuchy)" (PAE S.18/19 P.34 p.XII). W innym miejscu z irytacją o rymarzu: „Informacji udzielał naogół niechętnie i obojętnie, nie potrafił też lub poprostu nie chciał opisać jakie rodzaje chomąt wykonywał, gdy pracował w swoim zawodzie. Jako informator ciężki do zdobycia" (PAN 478/449). Nie ma w indeksach wulgarnych epitetów, jednakże przywołane przykłady świadczą dobitnie o wartościującej dosadności używanych określeń, które za pośrednictwem pisemnego przekazu wydają się zmiękczać lub niwelować rozmiar rzeczywistych uczuć ${ }^{9}$, jakie mogą towarzyszyć pracy badawczej. Warto

\footnotetext{
${ }^{8}$ Wyliczenie Moszyńskiego pokazuje trud zadania dokumentacyjnego, jakiego podejmują się etnografowie. Przy założeniu, że na jedno z 226 pytań przypadają dwie minuty odpowiedzi, indagacja będzie trwała około siedem i pół godziny.

${ }^{9}$ Doświadczenie pokazuje, że uwagi tego rodzaju nie oddają w pełni żywionych emocji, do których badacze mają prawo. Stanowią one wyraz afektu często poddany autocenzurze wynikającej ze swoiście rozumianej poprawności czy decorum. Sporządzanie indeksów może bowiem pełnić funkcję kompensacyjną i katarktyczną, co pozwala w choćby minimalnym stop-
} 
pamiętać, że swoistą jednostką miary etnograficznej w tym względzie będzie eufemistyczna kategoria "dobry informator" i wszelkie odchylenia od niej. Co się zaś tyczy osoby etnografa i ocen przez niego czynionych, to można celować w treści, które ujawnia jakby mimochodem, na przekór sobie. Warto zatem czytać indeksy między wierszami, szukając zwierciadlanego odbicia badacza tam, gdzie - jak mogłoby się wydawać - nie powinno go być wcale. Właśnie pod tym względem staje się możliwe dostrzeżenie rozdźwięku w stosunku etnografów względem rozmówców. Co innego zdają się deklarować na kartach artykułów i książek, co innego pokazują materiały archiwalne niedostępne postronnym.

\section{Wnioski}

Zapisy konkretnych treści, ujęte indeksami, zdradzają silnie reifikujące podejście względem rozmówców, przez co poniekąd oddają one charakter, jaki zwykła przyjmować $\mathrm{w}$ tradycyjnej etnografii relacja między badaczem a badanym. Joanna Tokarska-Bakir, omawiając zależność między stylem opisu a charakterem etnograficznego spotkania, rekapituluje: „styl to człowiek. Można pożyczać myśli, ale nie da się zawłaszczyć języka. Zawsze w końcu zdradzi on »miejsce« i rzeczywisty przebieg naszego spotkania z obcością" (Tokarska-Bakir 1995: 15).

Przez wzgląd na charakter, to jest pochodzenie i okres powstania przywoływanych materiałów, może się wydawać, iż jest to próba rozrachunku z rozliczonym już albo też od jakiegoś czasu martwym paradygmatem. Po pierwsze, zaprezentowana analiza nie stanowi chronologicznej rewizji modyfikacji rodzimego dyskursu etnograficznego. Jej celem było pokazanie „miejsc” zdradliwych, obnażających meandry praktyki terenowej i takie jej znaczenia, które chciałoby się zakryć, ponieważ z dzisiejszej perspektywy stanowią dowód niechlubnego dziedzictwa. Nie wypada jednak dociekać, czy jest to skutek amnezji, czy też znamię ocalającego wyparcia. Po drugie, zaprezentowany dobór materiałów miał na celu uniknięcie odwoływania się do indeksów opisujących jeszcze żyjących „informatorów”. Pomimo prowadzonych obecnie dyskusji dotyczących partnerskich sposobów traktowania rozmówców oraz dopuszczania ich czy uwzględniania ich głosu $\mathrm{w}$ trakcie pisania tekstów antropologicznych, wciąż można natrafić na indeksy sprokurowane podług dawnych wyznaczników przydatności. Upewnia o tym wgląd w powstałe po $1990 \mathrm{r}$. materiały terenowe rozmieszczone $\mathrm{w}$ rozmaitych ośrodkach etnograficznych, zarówno akademickich, jak i muzealnych, na terenie całej Polski.

Zasadniczym problemem związanym z indeksami etnograficznymi jest zaufanie, a raczej jego brak. W świetle indeksów etnograficznych - równie dobrze

niu odreagować czy zrzucić „kompost” przykrych doświadczeń albo wysłuchanych historii (Kość-Ryżko 2013: 18). Te „trudne” doświadczenia wymagają od badacza wypracowania szeregu technik i sposobów radzenia sobie z konfliktami wewnętrznymi, dysonansem czy niechęcią przed ujawnianiem emocji nie licujących z profesjonalnym wizerunkiem (Kuźma 2013: 77). 
można by je nazwać inwentarzami antropologicznymi, uszczerbku (choćby potencjalnego) doznali rozmówcy badaczy, stali się bowiem bez swojej wiedzy i zgody przedmiotem reifikującego opisu i ocen. Osoby, z którymi rozmawiali etnografowie, na poziomie reprezentacji były sprowadzane do postaci mierzalnego "towaru", ich wartość szacowano przede wszystkim pod względem przydatności dla sprawnej realizacji badań. Można w tym widzieć naruszenie niepisanych, społecznie warunkowanych i intuicyjnie rozumianych reguł międzyludzkiego współżycia. Owo naruszenie zachodziło najprawdopodobniej nie tylko na płaszczyźnie etnograficznej władzy tekstowej, ale musiało znajdować przełożenie na relacje zawiązywane $w$ terenie. Trudno bowiem oddzielić działania i postawy od sposobu myślenia i konceptualizacji, gdy te są silnie zapośredniczone przez dyskurs profesjonalny konserwujący asymetrię między badaczem a badanym, między opisującym a opisywanym. Jakkolwiek nie pozbawieni sprawczości informatorzy mogli w ten czy inny sposób stawiać opór indagacjom, tak na poziomie deskrypcji pozostawali bezbronni, wszak poza nimi leżała decyzja, co ostatecznie zostanie odnotowane. Jeśli uwzględnić trwałość dokumentów, będące w ich dyspozycji widły nigdy nie mogły się stać ekwiwalentem pióra. Skala ich podatności na działanie dyskursu etnograficznego kryła się w braku równoważnych względem pisma narzędzi (Goody 2006: 185), jak również braku dostępu do samego dyskursu. Wykluczenie miało zatem wymiar podwójny.

Opisy zawarte $\mathrm{w}$ indeksach, jakkolwiek neutralne w brzmieniu czy stanowiące konsekwentną realizację programu zadanego w kwestionariuszu, poprzez nagromadzenie zyskały dodatkowe znaczenie, stając się nieraz szczególnego rodzaju kartoteką. Fakt ten wpływa na ważkość informacji w nich zawartych. Przypisanie określonych cech i właściwości w tym kontekście może nosić znamiona stygmatyzacji. Ponadto dokonana redukcja do kilku arbitralnie przyjętych parametrów jest nie tylko czynnością dehumanizującą, ale także pozbawieniem prawa do odmowy. Wyzucie objętych takim trybem opisu rozmówców z możliwości decydowania o jego treści stanowi znamię wyrządzonej krzywdy, godzi bowiem $\mathrm{w}$ wartość, jaką jest owo upragnione przez etnografów zaufanie (por. Pietrowiak 2013). Ponadto możliwość późniejszego dotarcia do tych materiałów stanowi swego rodzaju niedyskrecję względem rozmówców, ponieważ bez ich wiedzy i woli, a nade wszystko udziału i obecności, osoby trzecie mają sposobność nabrania o nich określonego przekonania. Wyrażone tam opinie są nie tylko uproszczeniem, lecz również mają moc esencjonalizującą.

Fragmentarycznie i szczątkowo zaprezentowano tu możliwe odczytanie materiałów archiwalnych. Ujęcie to celowo marginalizuje perspektywę samych badaczy, ograniczając ją przede wszystkim do wytworzonych przez nich reprezentacji kontaktu etnograficznego. Ma to na celu uniknięcie sytuacji, w której mogłoby dojść do przesłonięcia uwikłania etycznego badaczy powodowanego czynionymi przez nich zapisami. Wynika to ponadto ze "stronniczości” dostępnych dokumentów, tylko etnografowie pozostawili bowiem po sobie materiały świadczące o rzeczonych kontaktach. Nie dysponujemy wspomnieniami i refleksjami drugiej strony, niegdysiejsi badani pozostają Baudrillardow- 
ską milczącą większością. O wyborze takiego ujęcia i sposobu przedstawienia materiału zadecydowało pragnienie wyraźnego zaprezentowania treści samych indeksów. Materiały te bowiem istnieją niejako wbrew obowiązującym obecnie normom etycznym oraz paradygmatom naukowym, stanowiąc nie tylko świadectwo przeszłości, ale i wyzwanie rzucone współczesnym "niewinnym" antropologom, budującym pozytywne mniemanie o sobie choćby na podstawie bon motu refleksyjności czy „zwrotu etycznego". Aleida Assmann (2013: 76-83) zwraca uwagę na społeczną rolę archiwum jako narzędzia pamięci, magazynującego dokumenty i ślady przeszłości pozostające $\mathrm{w}$ stanie nieustannej gotowości. Owo trwanie na przekór czasowi pożółkłych inskrypcji archiwalnych stawia wobec pytania o skalę i powody niepamięci profesjonalnej rodzimych etnologów. Rzecz jasna, gdy powstawały, hołdowano innym standardom postępowania z rozmówcami, inna też była poetyka pisania etnografii, jednakże milcząca obecność materiałów - znajdujących się na wyciągnięcie ręki - prowadzi do zastanowienia nie tylko nad przeszłymi praktykami, lecz również nad kulisami współczesnej „,kuchni” badawczej. Badania z tego zakresu znajdują się dopiero w stadium rozwoju i jeśli są prowadzone, dotyczą "obcego" dziedzictwa (Duszeńko-Król 2014; Maj, Trebunia-Staszel 2013). Warto zatem zastanowić się nad wewnętrznym oporem oraz przeszkodami utrudniającymi podejmowanie podobnej tematyki względem dziedzictwa rodzimego.

Wobec powyższych uwag będą zrozumiałe opór, zastrzeżenia czy wręcz zdecydowane głosy sprzeciwu. Tym niemniej problematyka indeksów pokrótce zarysowana w tekście doprasza się dalszej, pogłębionej i wieloaspektowej analizy wynikającej ze złożoności omawianego zagadnienia. Tekst niniejszy jest zatem ledwie anonsem i pierwszą z cyklu kilku zaplanowanych publikacji. Warto przy tym pamiętać, że zasadniczym zadaniem, jakie sobie tutaj postawiono, było dobitne wyartykułowanie jednego, spośród wielu dostępnych, spojrzenia, które uniknęłoby tłumaczeń dotyczących tego, co ze strony rozmówców może spotkać samego etnografa. To osobny temat względem dyskursywnie uprawomocnionej praktyki indeksowania, klasyfikowania i oceniania rozmówców. Przyjętą perspektywę celowo zogniskowano na ukrytej logice procedur etnograficznych.

\section{Literatura}

\section{Publikacje}

Agamben, G. (2010). Nagość. Przeł. K. Żaboklicki. Warszawa: W.A.B.

Appadurai, A. (2005). Nowoczesność bez granic. Kulturowe wymiary globalizacji. Przeł. Z. Pucek, Kraków: Universitas.

Assmann, A. (2013). Między historia a pamięcia. Antologia. Przeł. M. Saryusz-Wolska. Warszawa: Wydawnictwo Uniwersytetu Warszawskiego.

Biały, Z., Żarnecka-Biały, E. (1963). Z zagadnień weryfikacji w terenowych badaniach etnograficznych. Prace Etnograficzne, 1: 9-82.

Brocki, M. (2011). Sposoby artykulacji potocznych doświadczeń a porządek doświadczenia wymuszony praktyką etnograficzną. W: T. Rakowski, A. Malewska-Szałygin 
(red.), Humanistyka i dominacja. Oddolne doświadczenia społeczne w perspektywie zewnętrznych rozpoznań (s. 47-58). Warszawa: Instytut Etnologii i Antropologii Kulturowej Uniwersytetu Warszawskiego.

Coetzee, J.M. (2009). Białe pisarstwo. O literackiej kulturze Afryki Południowej. Przeł. D. Żukowski. Kraków: Znak.

Czachowski, H., Słomska-Nowak, J. (2011). Przedmowa. Materiaty Muzeum Etnograficznego w Toruniu, 2, 7-10.

Damrosz, J. (1996). Myśl teoretyczna w polskiej etnografii i etnologii w okresie powojennym (1945-1989). Warszawa-Siedlce: Wyższa Szkoła Rolniczo-Pedagogiczna.

Duszeńko-Król, E. (2014). Kolekcja fotograficzna Institut fur Deutsche Ostarbeit, Krakau 19401945. Kraków: Wydawnictwo Uniwersytetu Jagiellońskiego.

Foucault, M. (1998). Nadzorować i karać. Narodziny więzienia. Przeł. T. Komendant. Warszawa: Fundacja Aletheia.

Foucault, M. (2010). Bezpieczeństwo, terytorium, populacja. Wykłady w Collège de France 1977-1978. Przeł. M. Herer. Warszawa: Wydawnictwo Naukowe PWN.

Gajkowa, O. (1954). Sprawozdanie z konferencji w sprawie badań terenowych nad rolnictwem i hodowlą z dnia 9 i 10 maja 1953 r. w Poznaniu. Lud, 41(2), 1268-1280.

Goody, J. (2006). Logika pisma a organizacja społeczeństwa. Przeł. G. Godlewski. Warszawa: Wydawnictwo Uniwersytetu Warszawskiego.

Jasiewicz, Z. (2011). Początki polskiej etnologii i antropologii kulturowej (Od końca XVIII wieku do roku 1918). Poznań: Instytut im. Oskara Kolberga.

Jasiewicz, Z. (red.). (1979). Funkcje społeczne etnologii. Poznań: PAN.

Kamocki, J. (1953). Przeglad kwestionariuszy etnograficznych wydanych w języku polskim. Poznań: PTL.

Kopczyńska-Jaworska, B. (1971). Metodyka etnograficznych badań terenowych. Warszawa: PWN.

Kość-Ryżko, K. (2013). Etnolog w labiryncie znaczeń kulturowych. Psychologiczne wyzwania badań terenowych. W: I. Kuźma (red.), Tematy trudne. Sytuacje badawcze (s. 1547). Łódź: Wydawnictwo Uniwersytetu Łódzkiego.

Kutrzeba-Pojnarowa, A. (1955). Międzyuczelniane obozy etnograficzne na Kurpiowszczyźnie Uniwersyteckiego Studium Historii Kultury Materialnej w latach 1952-1954. Kwartalnik Historii Kultury Materialnej, 3(1), 224-236.

Kuźma, I. (2013). Wprowadzenie do antropologicznych badań wśród bezdomnych kobiet. Charakterystyka relacji dialogicznej. W: I. Kuźma (red.), Tematy trudne. Sytuacje badawcze (s. 65-89). Łódź: Wydawnictwo Uniwersytetu Łódzkiego.

Latour, B. (2012). Wizualizacja i poznanie: zrysowywanie rzeczy razem. Przeł. A. Derra, M. Frąckowski. Avant, 3, 207-257.

Libera, Z. (1995). Lud ludoznawców. Kilka rysów do opisania fizjognomii i postaci ludu naszego czyli etnograficzna wycieczka po XIX wieku. W: A. Posern-Zieliński (red.), Etnologia polska między ludoznawstwem a antropologia (s. 137-152). Poznań: Wydawnictwo Drawa.

Maj, M., Trebunia-Staszel, S. (2013). Nazistowskie badania antropologiczne i ludoznawcze na Podhalu. Dokument i pamięć. Konteksty, 300(1), 122-140.

Moszyński, K. (1925). W sprawie zbierania wiadomości, dotyczących ludowej kultury materjalnej w Polsce. Polska Oświata Pozaszkolna, 1, 28-36.

Moszyński, K., Klimaszewska, J. (1932). Atlas kultury ludowej w Polsce. Zeszyt I. Kraków: Księgarnia Gebethnera i Wolffa. 
Pietrowiak, K. (2013). Kłamstwo, uczciwość, zaufanie. Problemy etyczne w badaniach na temat życia osób niewidomych. Lud, 97, 267-290.

Posern-Zieliński, A. (1973). Kształtowanie się etnografii polskiej jako samodzielnej dyscypliny naukowej (do 1939 r.). W: M. Terlecka (red.), Historia etnografii polskiej, Wrocław: Ossolineum.

Sekula, A. (2010). Społeczne użycia fotografii. Przeł. K. Pijarski. Warszawa: Wydawnictwo Uniwersytetu Warszawskiego.

Sprawozdanie (1954). Sprawozdanie z badań terenowych Polskiego Towarzystwa Ludoznawczego w 1952 r. Lud, 41(2), 1259-1267.

Stelmachowska, B. (1946). O styl i obyczaj rodzimy na Ziemiach Odzyskanych. Przegląd Zachodni, 2(1), 9-21.

Stelmachowska, B. (1953). Na torach badawczych etnografii Pomorza. Głos Uczelni, 11(8), 8-9.

Stelmachowska, B. (1955). Trudności badawcze etnografa w terenie. Głos Uczelni, 24(3), 5.

Tagg, J. (2011). Maszyna archiwizacyjna - lub aparat fotograficzny i szafa kartotekowa. Przeł. K. Pijarski. W: K. Pijarski (red.), Archiwum jako projekt - poetyka i polityka (foto) archiwum (s. 42-55). Warszawa: Archeologia Fotografii.

Tokarska-Bakir, J. (1995). Dalsze losy syna marnotrawnego. Projekt etnografii nieprzeźroczystej. Konteksty, 49(1), 13-22.

Wróblewski, F. (2014). Pozanaukowe wyznaczniki zainteresowań badaniami regionalistycznymi. W: A.W. Brzezińska, J. Schmidt (red.), Regiony i regionalizmy w Europie. Badania - kreacja - popularyzacje (s. 45-61). Poznań: PTL.

Zawistowicz-Adamska, K. (1948). Społeczność wiejska. Łódź: Polski Instytut Służby Społecznej.

Zielinski, S. (2010). Archeologia mediów. O głębokim czasie technicznie zapośredniczonego stuchania i widzenia. Przeł. K. Krzemieniowa. Warszawa: Oficyna Naukowa.

Znamierowska-Prüfferowa, M. (1932). Muzeum Etnograficzne U. S. B. w Wilnie i jego przyszłość. Lwów-Wilno: Muzeum Etnograficzne U. S. B. w Wilnie.

Znamierowska-Prüfferowa, M. (1948). Ochrona zabytków kultury ludowej. Poradnik terenowy. Torun: Centralny Instytut Kultury.

Znamierowska-Prüfferowa, M. (1959). Rola Muzeum Etnograficznego i skansenu w Toruniu. Torun: Muzeum Etnograficzne.

II. Archiwalia i druki ulotne

Ankieta nr 1-2 (1948). Polski Atlas Etnograficzny. Ankieta Nr 1-2. Lublin, archiwum IEiAK UJ, kwestionriusz nr 2.

Instrukcja (1954). Instrukcja organizacyjna, program i szczegótowy rozkład zajęć Międzyuczelnianego Obozu Etnograficznego Studium HKM na rok 1954. Maszynopis, archiwum IEiAK UW, teczka MOE III/1954.

Judenko, K. (1953a). Wyciąg z protokołu posiedzenia Komisji Etnograficznej. Kraków w dniach 27, 28.IV.1953 r. (s. 2-4). W: Protokoty P.A.E. 1953-1955. Niezinwentaryzowany maszynopis, archiwum IEiAK UŚ.

Judenko, K. (1953b). Trzecie posiedzenie Komisji Etnograficznej w dn. 22.XI.br. godz. 10:30, pokój 115 (s. 10). W: Protokoty P.A.E. 1953-1955, niezinwentaryzowany maszynopis, archiwum IEiAK UŚ.

Klimaszewska, J. (1971). Folklor Torunia. Wprowadzenie i kwestionariusz. Torun, maszynopis, archiwum IEiAK UJ, kwestionariusz nr 262. 
Kwestionariusz I (1953). Kwestionariusz z zakresu hodowli $i$ rolnictwa, do badań terenowych w 1953 r. dla Polskiego Atlasu Etnograficznego. B.m., archiwum własne autora.

Kwestionariusz II (1953). Kwestionariusz nr 2 z zakresu hodowli i rolnictwa do badań terenowych w 1954 r. dla celów Polskiego Atlasu Etnograficznego. B.m., archiwum własne autora.

Moszyński, K. (1930). Kwestionariusz 1930. Rękopis, archiwum IEiAK UJ, materiały terenowe nr 7856/136.

Moszyński, K. (b.d.w.). Kwestionariusz do kultury ludowej. Maszynopis, archiwum IEiAK UJ, kwestionariusz nr 63.

\section{SUMMARY}

Ethnographic indexes in Polish anthropologists' fieldwork in the 20th century

The article presents the "archeology" of the process of shaping ethnographic research methodology in Poland. The author uses archival fieldwork materials gathered in the $20^{\text {th }}$ century, created by employees of anthropological research institutions, which belonged to various universities, museums, academies of sciences and other research units. Among the extensive resources analyzed in this article there are materials from field research under the supervision of Kazimierz Moszyński (the first half of the $20^{\text {th }}$ century), concerning Polish spiritual culture. Another set of resources is constituted by the Polish Ethnographic Atlas materials, a project initiated by Moszyński, but mostly continued by his follower - Józef Gajek (the second half of the $20^{\text {th }}$ century).

The issues in question are situated at the intersection of three theoretical perspectives. They are: the post-Foucault's critical theory concerning the relationship of power and domination, media studies perspective, focusing on the mechanisms and tools of data administration, and, finally, the literacy theory emphasizing the relationship between communication modes as well as thinking styles and logic of social organization.

The ethnographic indexes featuring in the title of the article involve records, metrics and descriptions added to fieldnotes, surveys or conversations transcripts. The indexes contain detailed descriptions of people contacted by anthropologists. These descriptions primarily relate to the origin, education, health and wealth of the interviewees, but also include opinions about the interlocutors' intelligence and their usefulness for further research. This way of describing was strongly marked by convention, due to which the indexes could provide an array of profiled information about each interlocutor or the entire studied community. They have been used to create catalogs and files of "informants", which further intensified the process of depersonalization.

The author argues that this practice of anthropologists, remaining beyond their interlocutors' knowledge and consent, allowed for schematic and objectifying description of persons encountered in field. As a result, it can be argued that this procedure, with reference to discursive legitimization, possessed the character of symbolic power. More importantly, this kind of description transformed the interlocutors into subjects of evaluations and classifications, enabling an assessment of "informants" primarily in terms of their suitability for efficient acquisition of research data.

Key words: Michel Foucault, archive, fieldnotes, description, index 